\title{
Corazón de aire
}

\section{Air Heart}

\section{María Leonor Santiago ${ }^{1}$ Fernando Javier Rodríguez Forgues ${ }^{1}$}

${ }^{1}$ Centro de Salud Municipal de Tres Arroyos Hospital Ignacio Pirovano, Buenos Aires, Argentina

Rev Argent Radiol 2022;85(Suppl S1):S21.

El aire presente en el tubo digestivo adopta una distribución característica en la radiografía simple de abdomen en supino, o bien en el escanograma de una tomografía

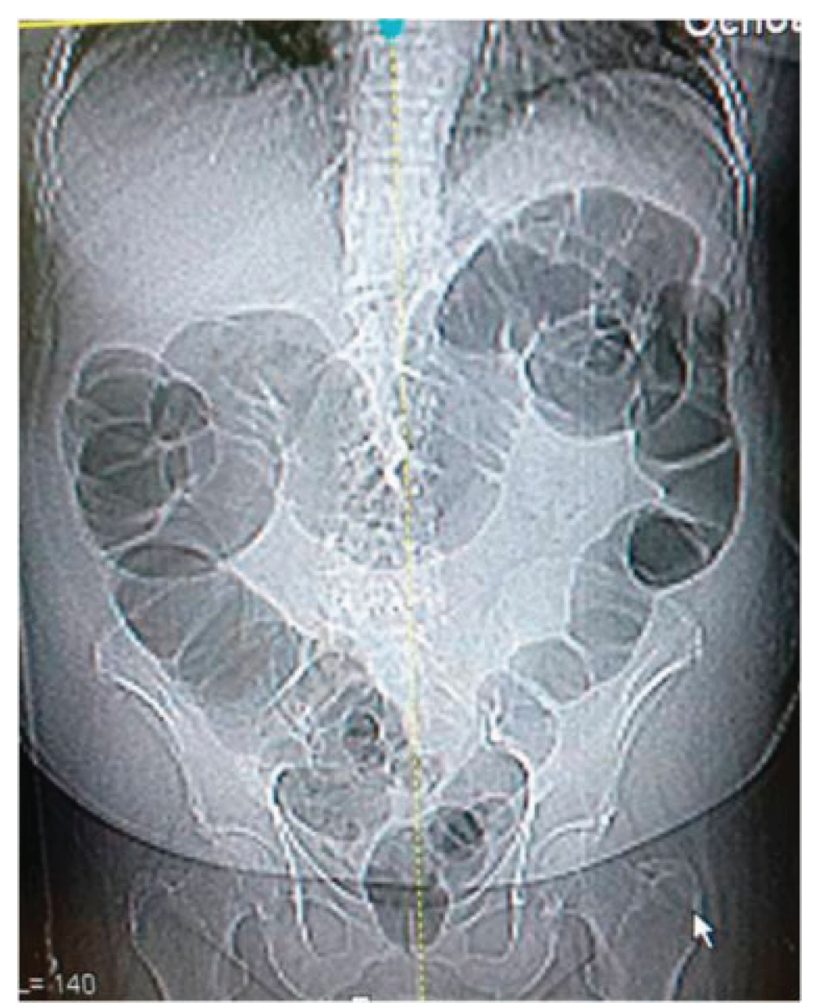

Fig. 1 Escanograma de tomografía computada previo a la adquisición de las imágenes en estudio de colonoscopía virtual.

received

April 23, 2018

accepted

June 20, 2018

published online

July 18,2018
Address for correspondence María Leonor Santiago, Centro de Salud Municipal de Tres Arroyos Hospital Ignacio Pirovano, Buenos Aires, Argentina (e-mail: mleosantiago@gmail.com).

computada. El gas localizado en el colon se visualiza periféricamente y es lo que se conoce como marco colónico (-Fig. 1). En el caso que se presenta a continuación, la paciente fue insuflada con aire ambiente a través de una sonda rectal para la realización de una colonoscopía virtual. La disposición que adopta el aire en el intestino grueso recuerda a la representación popular de un corazón (-Fig.2).

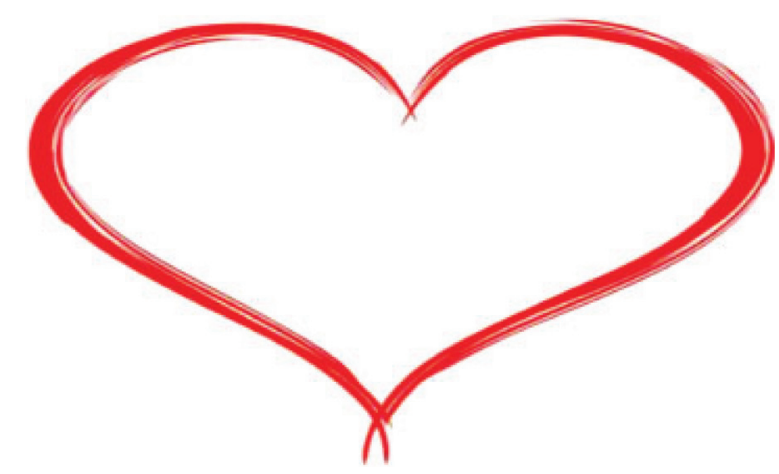

Fig. 2 Dibujo convencional de un corazón.

(C) 2018. Asociación Civil Sociedad Argentina de Radiología and Federacion Argentina de Asociaciones de Radiología, Diagnóstico por Imágenes y Terapia Radiante. All rights reserved.

This is an open access article published by Thieme under the terms of the Creative Commons Attribution-NonDerivative-NonCommercial-License, permitting copying and reproduction so long as the original work is given appropriate credit. Contents may not be used for commercial purposes, or adapted, remixed, transformed or built upon. (https://creativecommons.org/ licenses/by-nc-nd/4.0/)

Thieme Revinter Publicações Ltda., Rua do Matoso 170, Rio de Janeiro, RJ, CEP 20270-135, Brazil 